\author{
21 - 23 JUNE $2019 \quad$ VIENNA, AUSTRIA
}

\title{
Socio-economic challenges faced by Kinnara people under the modern social transformation
}

Dr.Geethani Amaratunga, Senior Lecturer, University of Kelaniya.

\begin{abstract}
:
In the Sri Lankan social organization, the 'Kinnara' people represents one of the bottom most strata in the Sinhalese caste hierarchy. In the Sri Lankan research literature, this research carries the objective of identifying the cultural features which had been unique to Kinnara community and their transformation in the modern times. Kinnara people had been identified as a tribe by M.D. Raghavan through an anthropological research. A rapid dissociation from those unique cultural features and a swift assimilation into the main society can be well observed. Therefore the research problem in this research is "What are the modern changes that can be seen among the Kinnara people?" Case study method was used to identify the current situation of the community. Kinnara people are spread out in the Central, Sabaragamuwa, North-Western and Western provinces. Even if it's dispersed in various parts of the country, a considerable population still lives in the hill country. After taking that into consideration, Central province was used as the field of research. Within the Sinhalese caste structure, weaving mats was the traditional caste occupation of the Kinnara people. It is known that they cultivated paddy and millet. But the contemporary Kinnara people do not show any distinctive cultural characteristics. It's fact that a majority of them are engaged in casual labour for their living. They have disengaged from the traditional dress codes and presently clothe-in accordance to the transformation. Changing of the hereditary occupational surnames in to surnames used by the upper castes also signifies the numerous modern shifts ongoing within the Kinnara people.
\end{abstract}

Key Words: Social organization, caste hierarchy, caste duties, traditional caste occupation, social transformation

All societies exhibit some system of hierarchy whereby its members are placed in positions that are higher or lower, superior or inferior, in relation to each other's. The concept of social stratification is made use of to refer to such classification or graduation and placement of people in society. Through this process of stratification people are fixed in social structure of the society, stratification assumes three main forms, caste, class, and estates. (Rao; 2001; p279) societies allocate their resources to their members in a variety of ways, however no society distributes their resources equally to all, and this results in social inequality.when categories of people differ in their access to societal resources, sociologists call this a system of social stratification (Goodman \& Goodman, 1996, p58) The origin of caste is one of the most important problem in the 
social history of India. Several researches have caste system but no definite conclusion has yet been arrived. In fact the nature of caste system is very complicated and it is difficult to recognize a particular factor which may be called responsible for its origin. In this regard professor D.N Majumdar has observed "the complex nature of caste structure is evident from the fact that after a century of pains taking and meticulous research in the history and function of the social system (singh;1998; p.20)

The Kinnara are largely upcountry caste group who appear to have originated from some tribal folk that found its way to the Island during some remote period. The physical traits display a curious blend of Australoid, Mediterranean and Negrito traits and whether they have at least partly descended from the lost tribe known as Nittavo. I Sri Lankan social organization the Kinnara people represents one of the bottom most statin the Sinhalese caste hierarchy. Rodi and Kinnara two main caste in the inferior layers of the subordinate caste order, can be identified as tribes as well as being castes. The appellation Kinnra by which these folk are generally known is often in sankritic literature to refer to a mythical being with a human figure and the head of a horse or with a horse's body and the head of a man. The Sinhala term Kindura which has derived from it however denotes a class of fabulous being, human above and bird like below (Hussein;2013;p.235)Even though they bore specified caste duties in Sri Lankan caste order , the tribal features are clearly visible among them.

Despite of the fact that the genesis of the Sri Lankan caste systems is hidden beneath the treasures of history it is clear that it has its originals in India, similar to the Sri Lankan Ethnic cultural characteristics (silva;1996/97,p.194)

The caste in the Indian caste system carries a division between Varna and Jati is widely spread and inherent to the Indian have over simplified the situation. To speak of a four caste system .for example is extremely misleading as we have noticed.

The Hindu social system Varna is only a references category: it is not functioning unit of social structure , and only refers broadly to the ascribed status of different Jati .It is also classificatory device .In it several jati with similar ascribed ritual status are 


\section{SOCIAL SCIENCE, HUMANITIES \& EDUCATION}

clustered together and are hierarchically graded. The three upper levels the Brahaman, the Kshathriya and the Vaishya .The Shudra the fourth levels includes a multiplicity of artisans and occupationally specialized. Jati who pursue clean non pulling occupations. (Dube; 2005; p48-49) An Indian carries several identification tags jati is commonly called caste in English.

In comparison to India the caste system in Sri Lanka is considered to be mild. Caste however was an important topic of sociological and anthropological research in Sri Lanka during the 1960's (eg; Leach1960,1961, Yalman 1967,Silva 1982,1992,Roberts 1984,Rayn 1993) The Sinhala caste system consisted of roughly about 15 caste groups ranging from a ruling aristocratic cast (Radala) to a servile beggar (Rodi) caste. (silva, sivapra gasam,Thanges; 2009; p21)

Table 01

Caste composition in Sinhala society

\begin{tabular}{|l|l|l|}
\hline Rank & Caste Name & Caste occupation \\
\hline 1 & $\begin{array}{l}\text { Govigama } \\
\text { Radala } \\
\text { Govigama } \\
\text { Patti }\end{array}$ & $\begin{array}{l}\text { Aristocracy } \\
\text { Free peasants } \\
\text { Herdmen }\end{array}$ \\
\hline 2 & Karawa & Fishing \\
\hline 3 & Salagama & Cinnamon work \\
\hline 4 & Durawa & Liquor making \\
\hline 5 & Hunu & Limestone work \\
\hline 6 & Nawandunna & Smiths \\
\hline 7 & Hena/Rada & Dhobi work \\
\hline 8 & Wahampura/Hakura & Sweet/Juggery \\
\hline
\end{tabular}




\begin{tabular}{|l|l|l|}
\hline 9 & Kumbal/Badahela & Pottery \\
\hline 10 & Dura & $\begin{array}{l}\text { Guardian of } 30 \text { tree/Royal } \\
\text { herdsmen/Mahouts }\end{array}$ \\
\hline 11 & Nakati/Berava & Drumming/Dancing \\
\hline 12 & Bathgama & Servants /potters \\
\hline 14 & Gahala & Executioner/Funeral work \\
\hline 15 & Kinnara & Mat weaving \\
\hline
\end{tabular}

Source; Jiggins (1979), Rayn (1993), Pieris (2001),Silva (2002)

Among them three relatively small caste groups, namely Gahala, Kinnara and Rodi (silva,sivapragasam,Thanges;2009,p 23) The bottom -most layer of the Sinhalese caste system the Rodi and Kinnara (Rayan;1993,p217-221) Kinnara caste is not considered as untouchables like Rodi. Kinnara caste were obligated to supply mats caste the like most other caste, the Kinnara too have had their traditional of mats. These mats known as "Kalala" or Dumbara rata peduru were traditionally made out of Niyada. (Hussein.2013.p 237)The very law caste Kinnara are relatively small group practically confined to the kandyan provinces and particularly to the districts of Kandy and Kurunagala. A few are to be found in southern province.

There is a number of folklore in Sri Lankan Society about the genesis of Kinnara community which differs geo graphically.one of them is as follws,"when as ancient king's garden was being raided of its flowers ,his nephew Kuru Mudaliya was set to catch the thief. At midnight he saw seven divine maidens alight from the married her, Her name was Kinnara Devi The young couple were so idle that the king threatened to behead them both if they did not offer some service to the crown. This made them so desponded that the god Sakra thought them the art of mat weaving which they do to this day believing that theirs is a divine art. (Samarasekara, 2001,p50-51) 


\section{SOCIAL SCIENCE, HUMANITIES \& EDUCATION}

21 - 23 JUNE 2019

VIENNA, AUSTRIA

\section{Research problem}

It is understood that the Kinnara people represents one of the bottom most strata in the Sinhalese caste hierarchy this caste have evolved with their tradition, cultural practices, social structure have been changed completely. Therefore the research problem is to identify "What are the modern transformation of the Kinnara people?

\section{Objective of the study}

$>$ To identify about the transformation of the Kinnara people in the present day.

$>$ To find out if the Kinnara community has got modernized along with the rest of society how those visible changes in the modern society.

$>$ To identify the role and the condition of the Kinnara people within their family and community as well as the role of the socio-economic framework.

Identify the divergence in their culture are the supplementary targets in this research.

\section{$\underline{\text { Limitation of the research }}$}

The Kinnara people are spread throughout the island, but it is not possible to study Kinnara people residing throughout the country due this reason, I have selected to study Kinnara people who live in upcountry only.

\section{Research methodology}

This research is based on primary as well as secondary data.to collect primary data on the Kinnara people related activities. The primary data were gathered within the study 
through interviews, observations, and questionnaire while the secondary data are gathered through books, journals as well as data gathered from the statistics department. Depending on the nature of the data it can be divided into two groups one is qualitative data and quantitative data (sarantakos;1998,p26)But certain things like the cultural transformation of Kinnara people can be expressed in numbers, those were identified under qualitative data.

\section{Data Analysis}

The Kinnra were famous for the beauty of mat weaving they manufactured, but they were also identified as wild and tribal like because of their proximity to jungles from where they extracted raw materials needed for their industry. The Sri Lankan caste system structured in a way that the economic factors and social benefits are concentrate on to the superior layers in the hierarchical order of castes. Hence the lower castes were deprived of the economic and social benefits.

In the kandyan era the Kinnra people supplied cordage, mats, whip cords, and other decorative items to the royal reserves as the primary caste obligation. Due to that caste occupation they were condemned by the social system back them and their less privileged status prevails even now.at present the traditionally mat weaving Kinnara people are barely engaged in their traditional profession. Kinnara community who inherited a highly creative art under the burden of caste discrimination are presently engaged in their craft as a profit making business in accordance to the modern socio economic environment .Even through Kinnara community live in various districts far away from each other, rotation between them exist, overcome the geographical bound rise. A considerable position of the Kinnara community lives at the upcountry in Sri Lanka.

1) The Kinnara people occupation of making all mats was a unique livelihoods within their community. The Kinnara folk songs explain the process of separating fibers from hana (hemp) it selling. However gradually with the modern technology this traditional 


\section{1 - 23 JUNE 2019 \\ VIENNA, AUSTRIA}

occupation have the generate but lucky there is a national \& international market for other kind of products made by hana such as small projects.

2) Rodi and Kinnara people occupy the lowest caste in Sri Lanka. So, women of these two communities were disallowed to cover their breast making them semi naked. These women were subjected to the sexual attraction of the superior communities due to this vulnerability. Since $20^{\text {th }}$ century the socio economic transformation of the Sri Lanka society paved the way for Kinnara women to overcome this situation. They started to wear a strip of cloth to hide their nudity.

3) There is an opportunity and an acceptance from the society to change the surname which cannot the lower caste inheritance within the Sinhalese caste system. Therefore changing of the surname has become a customary for the lower caste descendants. But it can be seen that the Kinnara people are still not eager to change their names and thereby keep on using their traditional family names. Surnames like, Kinnara Jathige, Pansal Waththe Gedara, Galbadawatte Gedra, Samudurayalage Gedara, Gonawala Pahala Gedara and Weddikkara Gedara are still on use and they clearly emphasize the caste inheritance. Even the first name of Kinnara people conveyed their less privileged status in the past. Instead of the names used by the elder generation using for e.g Puhula, Wattakkaya, Kiriya, Punchi Wasthuwa,Tikiri, Lucy and Baby. Second generation using names like karunawathi,anulawathi,Irangani, Padmini and Sumanawathi. The younger generation of the Kinnara people, possess names such as Munamalgahawaththe Gedara Kanishka, Henewela Pahala Gedara Indunath Udaya Kumara and Sriyani Pushpa Kumari.

\section{Conclusion}

In conclusion the study was able to identity many changes within the Kinnara community in the present day .Mat weaving was their traditional occupation in the olden times, but at present they are engaged in various occupations. Engagement in various occupations instead of mat weaving which was the traditional life style. Kinnara 


\section{$2^{\text {nd }}$ International Conference on}

\section{SOCIAL SCIENCE, HUMANITIES \& EDUCATION}

people are speedy mix with other castes. More recently found Kinnara village still had its 'dumbara rata paduru' and 'pan paduru' industries, though another considerable settlements in Kurunagala district people by descendants of some folk. Who had migrated from Kurunagala to Kandy to search for good manufacturing 'kalala'. The remodeling of the Kinnara society parallel the changes at the mainstreams is an inevitable phenomenon. Divergent to the primitive tribal characteristics accommodated at the past, today it is modernized community living in Sri Lankan society. Weaving mats which was the traditional caste occupation has turned into a macro scale business acquiring the commercialized objective at present. 


\section{SOCIAL SCIENCE, HUMANITIES \& EDUCATION}

21 - 23 JUNE 2019

VIENNA, AUSTRIA

\section{References}

Goodman Mariln and Goodman Norman, (1996) Introduction to sociology; NTC publishing group Illinois, U.S.A.

Hussein Asiff (2013), Caste in Sri Lanka; from ancient time to the present day; Neptune Publications (pvt) Ltd, Sri lanka.

De silva M.U, 1996 /1997 fourth edition, Published by Department of sociology, University of Ruhuna Sri lanka.

Dube S.C, (2005), Indian society, National book trust, India.

Silva Kalinga Tudor ,Sivapragasam p,p,Thanges Paramsothy, (2009), castless or casteblind Dynamics of concealed caste Discrimination, Social exclusion and Protest in Sri Lanka, Kumaran Book House, Colombo-Chennai.

Samarsekara Sepala, (2001), Primitive people in Sri lanka, S Godage brothers Colombo.

Sarantakos S, (1998), Social Research, Mc millan press Ltd, London. 